\title{
Effects of Mandatory School-time Practice on the Preparation of Vocational Medical College Students for their Profession
}

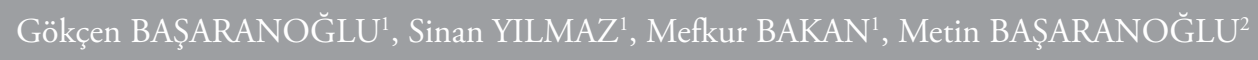

'Department of Anesthesiology and Reanimation, Bezmialem Vakif University School of Medicine, Istanbul, Turkey

${ }^{2}$ Department of Internal Medicine and Gastroenterology, Bezmialem Vakif University School of Medicine, Istanbul, Turkey

\section{ABSTRACT}

Objective: The goal of this study was to evaluate the effects of mandatory school-time practice on the preparation of second-year anesthesia nurse students for their future profession.

Methods: A questionnaire was filled out by second-year anesthesia nurse students for situational awareness evaluation at the beginning of the term. The questionnaire form consisted of 19 questions and was prepared according to the basic practice on anesthesia course. Certain practi$\mathrm{cal}$ anesthesia procedures were obliged to make a certain minimum number for anesthesia nurse students. At the end of the year, the same questionnaire form was filled out again.

Results: At the beginning of the study period, the ratio of students who did not feel were ready for their future professional life was $60 \%$, whereas this ratio decreased to $20 \%$ by the end of the study period.

Conclusion: Application of mandatory practical procedures for anesthesia nurse students seem to be very important in preparing them for their future professional life.

Keywords: Anesthesia nurse students, clinic, education, practice

\section{Introduction}

The 2-year training program in the anesthesia department of vocational health schools is taken in four terms. Applicants come to our school through transition from medical vocational high schools (VHSs) or from high schools through university entrance exams. Students who graduate in the 2-year program are expected to work independently with the patient under strict discipline in the operating environment.

The aims of this study were to determine the situation of our students according to the results of the survey that we applied to second-grade fourth-term students of the vocational school, to understand whether or not they are ready to stay alone with the patient, and by observing the shortcomings of our own and our students, to apply this study in practice in order to prepare our students for the professional life.

\section{Methods}

A 19-question survey was applied to the fourth-semester anesthesia students twice, at the beginning and at the end of the semester. Eight of the survey questions were about practical work in anesthesia, 4 questions about understanding the lessons, 4 questions about status inquiry, 2 questions about demographic data, and 1 question about distance education (Appendix 1). Students were obligated to fill out an internship record book according to the results of the first questionnaire. They were required to see a certain number of patients until the end of the term, observe the working of anesthesia devices and monitors by visiting every operation table, and observe the anesthesia environment from outside operating rooms, thereby increasing their knowledge and experience. 


\section{Statistical analysis}

Fisher's exact test was used for the comparison of data. $\mathrm{P}<0.05$ was considered significant.

\section{Results}

A total of 25 students participated in the survey. The average age of the students was 21 (20-26 years). Only 7 students were graduates of medical VHSs. The results of the questionnaire filled at the beginning and end of the term are shown in Table 1 . No student wanted to take the anesthesia course as distance education. The proportion of students who did not feel ready for duty after graduation was $60 \%$ ( 15 people) at the beginning of the term and this decreased to $20 \%$ ( 5 people) at the end of the term. Of 5 students, 3 did not feel ready for practising as anesthesiologists. At the beginning of the term, the number of students who did not feel ready for practice was only 7 and these students felt incompetent regarding issues such as intubation and inserting laryngeal masks. At the end of the term, 6 students overcame their deficiencies.

\section{Discussion}

Currently, young students prefer the 2-year programs in VHSs so as to begin to work early. Anesthesia nursing program of VHSs is a 4 year program. Anesthesia training programs were started across the Turkey after the VHSs anesthesia graduate programs started to accept students. Now, students graduated from regular high schools get 2 years rigorous education instead of 4 years education. But, sufficiency of this duration of education is questionable.

There are 955 VHSs in Turkey according to the 2014 data from the Council of Higher Education (CHE). Because the right of transition without examination from vocational and technical secondary education institutions to VHSs was provided, a heterogeneous student profile occurred in classrooms; however, this situation adversely affected the quality of education according to Alkan et al. (1). These authors observed that $35 \%$ of students who were placed in VHSs in 2013 and 2014 were graduates of Anatolian High Schools or Science High Schools. Because this situation may lead to compliance problems in students, they should be carefully monitored.

The provision of visual and audio infrastructure is important to ensure the permanence in VHS education. Generally, people remember only $10 \%$ of what they read, $20 \%$ of what they hear, $30 \%$ of what they see, $50 \%$ of what they see and hear, and $70 \%$ of what they say, but they remember $90 \%$ of what they say and do (2). Thus, technical equipment is important. In some Turkish universities, students only practise on models and graduate without barely touching a patient.
Table 1. The answers of the students to questionnaire at the beginning and end of the term

\begin{tabular}{|c|c|c|c|}
\hline Questions & $\begin{array}{l}\text { Beginning } \\
\text { of the } \\
\text { term } \\
\text { (yes/no) }\end{array}$ & $\begin{array}{l}\text { End of } \\
\text { the term } \\
\text { (yes/no) }\end{array}$ & $\mathbf{p}$ \\
\hline $\begin{array}{l}\text { 1. If you were a graduate } \\
\text { now, would you feel ready } \\
\text { for the task? }\end{array}$ & $10 / 15$ & $20 / 5$ & $0.0086^{*}$ \\
\hline $\begin{array}{l}\text { 4. Do you have a good } \\
\text { command of anesthesia } \\
\text { device? }\end{array}$ & $13 / 12$ & $22 / 3$ & $0.01 *$ \\
\hline $\begin{array}{l}\text { 5. Do you have a good } \\
\text { command of the monitors? }\end{array}$ & $23 / 2$ & $25 / 0$ & 0.48 \\
\hline $\begin{array}{l}\text { 6. Are you able to follow } \\
\text { up with an anesthesia } \\
\text { patient independently? }\end{array}$ & $20 / 5$ & $23 / 2$ & 0.41 \\
\hline $\begin{array}{l}\text { 7. Can you notice the gas } \\
\text { connections and system } \\
\text { errors in the anesthesia } \\
\text { device? }\end{array}$ & $10 / 15$ & $21 / 4$ & $0.0031 *$ \\
\hline $\begin{array}{l}\text { 8. Can you receive, stabilize, } \\
\text { and render the service to } \\
\text { the patient independently } \\
\text { at the stage of } \\
\text { post-anesthesia recovery? }\end{array}$ & $24 / 1$ & $22 / 3$ & 0.6 \\
\hline $\begin{array}{l}\text { 9. Do you believe as a } \\
\text { student that you can } \\
\text { sufficiently concentrate on } \\
\text { your lessons? }\end{array}$ & $20 / 5$ & $22 / 3$ & 0.7 \\
\hline $\begin{array}{l}\text { 11. Do you have difficulty } \\
\text { understanding the lessons? }\end{array}$ & $6 / 19$ & $2 / 23$ & $<0.0001$ * \\
\hline $\begin{array}{l}\text { 12. Do you have sufficient } \\
\text { hours for practice? }\end{array}$ & $25 / 0$ & $25 / 0$ & \\
\hline 13. Do you feel at peace? & $20 / 5$ & $23 / 2$ & 0.4 \\
\hline 14. Do you feel happy? & $17 / 8$ & $23 / 2$ & 0.07 \\
\hline $\begin{array}{l}\text { 15. Do you feel guilty } \\
\text { (inability to study, } \\
\text { concentrate on the lessons, } \\
\text { and find time for the } \\
\text { lessons)? }\end{array}$ & $12 / 13$ & $20 / 5$ & 0.07 \\
\hline $\begin{array}{l}\text { 16. Can you sufficiently } \\
\text { follow the lessons? }\end{array}$ & $21 / 4$ & $23 / 2$ & 0.6 \\
\hline
\end{tabular}

In a study by Günay and Özer, the ratio of student/instructor is approximately 52 in VHSs in Turkey for academic year 2012-2013 (3, 4). In academic year 2014-2015, 2 associate professors and 5 assistant professors taught in the anesthesia department of our university and the ratio is approximately 5 students to 1 instructor. We believe that the quality of education in our university increased with the diversity of instructors as well as infrastructure, lab facilities, and patient population. 
Our university hospital is a large institution with the facility to practise anesthesia in 24 different units. Of them, 20 are main operating rooms and the others are external units. We have a model laboratory in the Gayrettepe campus of the VHS. Our students are capable of following routine and special procedures in real patients and also have the opportunity to perform applications on models.

Anesthesia is a department that requires discipline and serious education (5). When summer internships were planned for the students of VHS, they were not willing to participate. Summer internship is an important practice where the students observe and learn for 30 days in order to prepare for their professional lives in future. In the study they performed about the role of the practice and summer internship in preparing for the professional life among the nursing students, Çaliskan et al. (6) found that the internship was a good opportunity to develop their skills. With the application of an internship record book, each student was provided with the opportunity to see a total of 220 patients in various departments, 100 until the end of the mid-term exam and 120 until the end of the final exam. By the time of the final exam, the students were expected to observe and sufficiently understand the working of anesthesia devices and monitors and also observe some difficult intubations including neonatal intubation in a real patient or a model. Students could reinforce their knowledge by taking up relevant homework and checking the materials that an anesthesiologist prepared for each operating room.

It was observed that the concerns of students regarding the changes in university life and difficulties in understanding the lessons in the first term were replaced by new concerns, such as starting professional life, the responsibility of a real patient, and finding a job in the last term.

Clinical training imparts consolidated theoretical knowledge to students and students have the possibility of application of the knowledge in a real environment. Clinical education leads to effective cognitive and psychomotor development and enhances the abilities to be a member of a group and make appropriate decisions (6). A study suggested that it was necessary that the clinical staff should actively include the student in work, and it was indicated that the clinical instructor and the clinic personnel played a major role in student education (7). There are studies showing that first year nursing students may have difficulties and anxiety in terms of communication and approach in clinical practice and hence, the second year is an appropriate time to start practical training by increasing the number of practice hours (8). Because most of our students are high school graduates, the number of the practice hours was increased in the second year. The rate of knowledge regarding gas connections and system errors in anesthesia equipment between the beginning and end of the term was significantly different in our students. With the application of an internship record book, students were allowed to switch the anesthesia machine on and off 30 times, were given small table-top tests to assess whether or not they could find the gas-system connection failures in the correct place and in a timely manner, and were provided instant feedback. While 24 students answered the question "Can you receive, stabilize and render the patient to the service alone at the stage of post-anesthesia recovery?" as "yes" at the beginning of the term, 22 students answered "yes" at the end of the term. This decrease may be because the students felt secure without knowing the possible risks and dangers due to inadequate knowledge. The number of students who had difficulty understanding the course significantly decreased at the end of the term. The question-answer method and rewarding the correct answer in theoretical and practical lessons may have a role in this. The feelings of guilt due to preparation for other exams other than anesthesia and studying elsewhere thereby not paying enough attention to the lessons can be shown as reasons of students not feeling at peace and happy in anesthesia. Although the students did not find the implementation of internship record book necessary at first, at the end of the term, they noted that it was useful for their professional life, their self-confidence increased, and they stated that they developed team spirit and discipline.

To conclude, because the slightest error leads to unwanted hazardous results, internship application is important for anesthesia technician students. Anesthesia practical internship should be made compulsory and applied to anesthesia students preparing for professional life.

Ethics Committee Approval: This study is an inquiry study for this reason there is no ethichs committee approval.

Informed Consent: There are no patients in this study.

Peer-review: Externally peer-reviewed.

Author Contributions: Concept : G.B.; Design - M.B.; Supervision - M.B.; Resources - S.Y.; Materials - M.B.; Data Collection and/or Processing - S.Y.; Analysis and/or Interpretation - G.B.; Literature Search - S.Y.; Writing Manuscript - G.B.; Critical Review - M.B.; Other - S.Y.

Conflict of Interest: No conflict of interest was declared by the authors.

Financial Disclosure: The authors declared that this study has received no financial support.

\section{References}

1. Alkan RM, Suiçmez M, Aydınkal M, Şahin M. Meslek Yüksekokullarındaki Mevcut Durum: Sorunlar ve Bazı Çözüm Önerileri. Yükseköğretim ve Bilim Dergisi 2014; 4: 133-40. 
2. Erişim linki: http://www.willatworklearning.com/2006/10/people_remember.html

3. Günay D. Türkiye'de meslek yüksekokulları, düzenleme çalışmaları ve öneriler. Türkiye'de Mesleki ve Teknik Eğitimin Kalitesinin Geliştirilmesi, Meslek Yüksekokullarında Kalite: Mevcut Durum, Sorunlar ve Çözüm Önerileri Konferansı: 06-07 Mart 2014, Çorum. Erişim linki: http://mtegm.meb.gov.tr/www/meslek-yuksekokullariegitim-ve-ogretimde-kaliteyi-tartisti/icerik/590.

4. Günay D, Özer M. Türkiye'de meslek yüksekokulları, mevcut durum, sorunlar ve çözüm önerileri (Taslak), 2014, Ankara: YÖK.
5. Başaranoğlu G, Başaranoğlu M. Meslek yüksek okulu öğrencilerinin anestezi ders başarısında disiplin ve eğitim yönteminin rolü. Bezmialem Science 2015; 3: 12-4.

6. Çalışkan T, Akgöz S. Sağlık yüksek okulu öğrencilerini mesleki yaşama hazırlamada yıl içi ve yaz stajlarının katkısı. Uludağ Üniversitesi Tip Fakültesi Dergisi 2005; 31: 9-13.

7. Chapman R, Orb A. The nursing students' lived experience of clinical practice. AEJNE 2000; 5: 2.

8. Öz F, Üstün B. Hemşirelik yüksek okulu birinci sınıf öğrencilerinin klinik uygulama öncesi ve sonrası anksiyete düzeylerinin belirlenmesi. Hemşirelik Bülteni 1995; 9: 57-64. 


\section{Appendix 1. The questions of the fourth-term question- naire of the anesthesia technician school}

1. If you were a graduate now, would you feel ready for the task? a) Yes

b) No

2. If the answer is no, why?

a) I do not feel qualified in terms of practice

b) I do not feel qualified theoretically

3. If your answer is "practice"?

a) Establishing vascular access (adult, child, and infant)

b) Inserting intubation and laryngeal mask (adult, child, and infant)

4. Do you have a good command of anesthesia device?

a) Yes

b) No

5. Do you have a good command of the monitors?
a) Yes
b) No

6. Are you able to follow up with an anesthesia patient independently?
a) Yes
b) $\mathrm{No}$

7. Can you notice the gas connections and system errors in the anesthesia device?
a) Yes
b) No

8. Can you receive, stabilize, and render the service to the patient independently at the stage of post-anesthesia recovery?
a) Yes
b) No

9. Do you believe as a student that you can sufficiently concentrate on your lessons?
a) Yes
b) No

10. If your answer is no, why?

11. Do you have difficulty understanding the lessons?
a) Yes
b) No

12. Do you have sufficient hours for practice?
a) Yes
b) $\mathrm{No}$

13. Do you feel at peace?
a) Yes
b) $\mathrm{No}$

14. Do you feel happy?
a) Yes
b) No

15. Do you feel guilty (inability to study, concentrate on the lessons, and find time for the lessons)?

a) Yes

b) $\mathrm{No}$

\section{Appendix 1. Continue}

16. Can you sufficiently follow the lessons?
a) Yes
b) No

17. Would you like to take the theoretical course remotely online provided your practical course is done in the operating room (listening to your teacher accompanied by slides from anywhere and at any time with internet access)?

18. What is your age?

19. Which high school have you graduated from?
a) Vocational high school
b) High school 